\title{
TRIPS-Plus Provisions on Patent under Indonesia's Bilateral Free Trade Agreement
}

\author{
Nurul Barizah \\ Faculty of Law, Universitas Airlangga \\ Jl. Dharmawangsa Dalam Selatan Surabaya \\ nurul.barizah@fh.unair.ac.id
}

\begin{abstract}
The protection for Intellectual Property Rights (HKI) with higher standards than the one mentioned in the Agreement on Trade-Related Aspects of Intellectual Property Rights (TRIPs), known as TRIPs-Plus, has become a crucial legal issue in bilateralism era nowadays. This research is aimed at analyzing the stipulations in TRIPs-Plus in the case of Patent which is mentioned in several Bilateral Free Trade Agreement (BFTAs), analyzing the existence of TRIPs-Plus in BFTA between Indonesia and its business partner countries, and analyzing whether Indonesia needs to revise its Constitution regarding Patent to fulfill such commitment. This was a normative legal research which used constitutional, conceptual, and comparative approaches. The findings show that most of BFTA which are already agreed by developed and developing countries with their business partner countries, in the case of Patent, contain the standards of TRIPs-Plus. Such stipulation is also found in Indonesian Japan Economic Partnership Agreement (IJEPA). However, the revision of Constitution about Patent should be based on not only bilateral commitment, but also national interests.
\end{abstract}

Keywords: TRIPs-Plus, Patent, Bilateralism, IJEPA, Indonesia

\begin{abstract}
Abstrak
Perlindungan Hak Kekayaan Intelektual (HKI) dengan standar yang lebih tinggi dari standar yang ditetapkan dalam Agreement on Trade-Related Aspects of Intellectual Property Rights (TRIPs), dikenal dengan TRIPsPlus menjadi salah satu isu hukum yang penting di era bilateralism sekarang ini. Penelitian ini bertujuan untuk menganalisa ketentuan TRIPs-Plus di bidang Paten yang terdapat dalam beberapa Perjanjian Perdagangan Bebas Bilateral (BFTAs), menganalisa keberadaan TRIPs-Plus dalam BFTA antara Indonesia dan negara mitra dagangnya, dan menganalisa apakah Indonesia perlu merevisi UndangUndang tentang Paten untuk memenuhi komitmen tersebut. Penelitian ini merupakan penelitian hukum normatif dengan menggunakan pendekatan perundang-undangan, konseptual dan perbandingan. Penelitian ini menyimpulkan bahwa mayoritas BFTA yang telah disepakati oleh negara-negara maju dan negara-negara yang sedang berkembang dengan negara mitra dagangnya, di bidang Paten, mengandung standar TRIPs-Plus. Ketentuan ini juga ditemukan dalam Indonesian Japan Economic Partnership Agreement (IJEPA). Akan tetapi, revisi Undang-Undang tentang Paten sebaiknya tidak hanya didasarkan pada komitmen bilateral saja, tetapi juga perlu mempertimbangkan kepentingan nasional.
\end{abstract}

Key Words: TRIPs-Plus, Paten, Bilateralism, IJEPA, Indonesia 


\section{Background}

In the last decade, Bilateral Free Trade Agreements (BFTAs) have becomes the main option for both developed and developing countries. ${ }^{1}$ Developed countries tend to use bilateralism because they thought that multilateralism of trade agreement is regarded as less effective to protect their interests. ${ }^{2}$ This can be seen clearly from the frequent occurance of deadlocks and resistances during multilateral negotiating forum, including its implementation. ${ }^{3}$

Sectors in the BFTAs negotiation is not only limited to trade in goods, but also includes a number of important issues beyond trade in goods. For example, market access, trade in services, investment liberalization and protection of investors' rights, intellectual property rights (IPR), government procurement, competition policy, labour and environmental standards. ${ }^{4}$ However, in general, the substance and the agreed standards in this BFTAs exceeds the substance and standards that have been agreed upon in the level of multilateral trade agreements (rounds of negotiations were organised and initiated by the WTO). ${ }^{5}$ Because of that, such Agreement is knows as the WTO-Plus Agreement. ${ }^{6}$ While in the field of IPR, such standard usualy known as TRIPs-Plus Standard.7

The TRIPs Agreement ${ }^{8}$ sets an internationally regulatory framework for the protection and enforcement of IPRs, but bilateral trade mechanisms ensure higher

\footnotetext{
${ }^{1}$ Kenneth Heydon and Stephen Woolcock, The Rise of Bilateralism; Comparing American, European and Asian Approaches to Preferential Trade Agreements, United Nations University, 2009, p. 10.

${ }^{2}$ Susan K. Sell, "TRIPs Was Never Enough: Vertical Forum Shiftings, FTAs, ACTA, and TPP”, J. Intellectual Property Law, Vol. 18, 2010-2011, p. 447.

${ }^{3}$ Mike Moore, A World Without Walls: Freedom, Development, Free Trade and Global Governance, Cambridge University Press, Cambridge, United Kingdom, 2003, p. 93-167.

${ }^{4}$ Martin Khor, Bilateral and Regional Free Trade Agreement: Some Critical Elements and Development Implications, TWN Third World Network, Malaysia, 2008, p. 1.

${ }^{5}$ Henning Grosse Ruse-Khan, “The International Law Relation between TRIPS and Subsequent TRIPSPlus Free Trade Agreements: Towards Safeguarding TRIPS Flexibilities?”, Journal of Intellectual Property Law, Vol. 18, No. 2, 2011, p. 1.

${ }^{6}$ Kenneth Heydon and Stephen Woolcock, Op.Cit., p. 7.

${ }^{7}$ Carlos M Correa, "TRIPs and TRIPs-Plus Protection and Impacts in Latin America", in Daniel Gervais (ed.), Intellectual Property, Trade and Development; Strategies to Optimize Economic Development in a TRIPs-Plus Era, Oxford University Press, 2007, p. 222; See also Kenneth Heydon and Stephen Woolcock, Ibid., p. 125-126;See also Nurul Barizah, "TRIPs Plus on Plant Varieties Protection under Indonesia-Japan Economic Partnership Agreement (IJEPA)", Yuridika, Vol. 24, No 1, 2009, p. 2.

${ }^{8}$ Agreement on Trade Related Aspects of Intellectual Property Rights (TRIPs) of 1994. (Marrakesh Agreement Establishing the World Trade Organization, Annex 1C, 15 April 1994, 33 I.L.M. 1197, 1201 (entered into force on $1^{\text {st }}$ January 1995).
} 
standards of IPR protection beyond that specified in the TRIPs Agreement. ${ }^{9}$ This TRIPs-Plus provisions is widely agreed in BFTAs between developed countries and developing countries, 10 including Indonesia. It means that IPR norms contained in the TRIPs-Plus is norms suitable for protecting IPR in developed countries, like the United States (US), Japan, European nations, and others. BFTAs tends to promotes developed countries's IPR norms to be implemented in developing countries as well. As the US Trade Promotion Authority stated that the purpose of BFTAs negotiation is to promote IPR rules that "...reflect a standard of protection similar to that found in United States Law."11

As a response, Drahos argued that standards and norms set out in the United States is a standard that is appropriate to the need of the American economy, which is suitable to the condition of American culture and philosophy, and not an international standard. ${ }^{12}$ Similarly, Abbott asserts that if the IP norms suitable to be applied for developed countries, like United States, these norms may not be appropriate when applied in developing countries. ${ }^{13}$ This means that the application of the principle of "one size fit all" in IPR protection is not appropriate. Carroll also asserts that the application of the standards and norms of IPR protection based on the principles of "one size fit all" for all countris is not fair. ${ }^{14}$ It is also contrary to the general principle of territoriality in IPR protection. Because of that, the application of IPR protection standards should be adjusted in line with the level of economic and technological development of a country.

${ }^{9}$ Anselm Kamperman Sanders, "Intellectual Property Treaties and Development", in Daniel Gervais (ed.), Intellectual Property, Trade and Development; Strategies to Optimize Economic Development in a TRIPs-Plus Era, Oxford University Press, 2007, p. 163.

${ }^{10}$ See variation in TRIPs-Plus Provisions of Selected US -FTAs in Carolyn Deere, The Implementation Game; The TRIPs Agreement and the Global Politics of Intellectual Property Reform in Developing Countries, Oxford University Press, 2009, p. 338.

${ }^{11}$ See Bipartisan Trade Promotion Authority Act of 2002, see Nurul Barizah, "The Implications of the US- Indonesia Free Trade Agreement on Access to Medicines and Conservation of Genetic Resources in Indonesia", dalam Alexander C. Candra (ed.), Checkmate! The US-Indonesia Bilateral Free Trade Agreement, Institute for Global Justice, Jakarta, 2007, p. 171.

${ }^{12}$ Peter Drahos, "Expanding Intellectual Property's Empire; The Role of FTA's, at http://bilateral.org/IMG/doc/Expanding IP Empire Role of FTAs.doc, accessed on 2 June 2014.

${ }^{13}$ F. M. Abbott, "Intellectual Property Provisions of Bilateral and Regional Trade Agreement in the Light of US Federal Law", International Centre for Trade and Sustainable Development, Issue Paper No 12, http://www.ipronline.org/unctadictsd/description.htm, accessed on 2 June 2014.

${ }^{14}$ Micheal W. Carroll, "One Size Does Not Fit All: A Framework for Tailoring Intellectual Property Rights”, Obio State Law Journal, Vol 70:6, 2009, pp. 1362-1433. 
According to Reichman, the patent system in the United States today is in a state of "dreadful mess and badly need reform". ${ }^{15}$ While in the field of copyright, Patry found that Copyright Act of the United States should be fixed.16 Interestingly, although the prevailing Acts relating to IPR protection in the United States from the perspective of American is still lack of perfect and contains a number of problems, such Acts must be implemented in the national jurisdiction of trading partner countries through BFTAs.

It is important to note for developing countries, the application of norms and standards of protection exceeds the TRIPs agreement is not appropriate for the time being, and also be contrary to the obligations of developing countries's governments in the fulfilment of the rights of citizens in specific sectors, like in education, health and agriculture. Despite a number of criticisms, BFTAs is growing rapidly, it is unlike to stopped. ${ }^{17}$ Indonesia for example, has signed Indonesia Japan Economic Partnership Agreement (IJEPA) ${ }^{18}$ and the Asean-China Free Trade Agreement (ACFTA). ${ }^{19}$ Furthermore, Indonesia is currenly negotiating BFTA with the United States and several countries in Europe and the Middle East.

Under the Law of Treaties, by signing bilateral agreement, contracting parties to the Agreement have to adjust its national laws inline with the provisions of the Agreement, and this is not exception to Indonesia. On the above basis, it means that Indonesia also required to amend the Act Number 14 of 2001 on Patent. This lead to problems because bilateral commitment does not always in harmony with national interest, or other public interests in the protection of patent.

15J. Reichman, "Charting the Collape of the Patent-Copyright Dichotomy; Premises for a Restructured International Intellectual Property System”, Cardozo Art and Entertainment Law Journal, Vol 13, 1994, pp. 475-517.

${ }^{16}$ See in general, William Patry, How to Fix Copyright, Oxford University Press, USA, 2012, p.50.

${ }^{17}$ Susan K. Sell, Op.cit, p. 449. See also Jean-Frédéric Morin, "Multilateralizing TRIPs-Plus Agreements: Is the US Strategy a Failure?”'The Journal of World Intellectual Property, Vol. 2, Issue 3, 2009, pp.175-197.

${ }^{18}$ Agreement between Japan and the Republic of Indonesia for an Economic Partnership, signed in Jakarta, 21 August, 2007.

${ }^{19}$ Framework on Comprehensive Economic Co-Operation between ASEAN and the People's Republic of China, Phnom Penh, 5 November 2002. 


\section{Statement of the Problems}

Based on the background above, the problems of this research can be formulated into three main questions. Firstly, what are the TRIPs-Plus provisions on Patent stipulated in the BFTAs in general? Secondly, whether BFTAs between Indonesia \& its trading partner consist of TRIPs-Plus provisions on Patent? Lastly, should Indonesian Patent Act be revised to meet such bilateral commitment?

\section{Research Objective}

There are 3 (three) main objectives of this research. Firstly, to analyse the TRIPs-Plus provisions on patent stipulated in the BFTA in general. Secondly, to examine the TRIPs-Plus provisios on patent which have been agreed under BFTAs between Indonesia and its trading partner. And thirdly, to evaluate whether revision in patent Act is needed to meet such bilateral commitment.

\section{Research Method}

In principle, the type of this research is normative legal research by using statutory conceptual, and comparative approaches. This statutory approach is done by reviewing all laws and regulations related to the questions of this research, including reviewing international agreements, bilateral agreements, and national legislations relevant to this research issues especially Patent Act. While international conventions covering TRIPs Agreement and Patent Cooperation Treaty (PCT). While conceptual approach used in this research to analyse legal concepts relevant to the questions of this research. Then, comparative approach also used to compare substantial aspects of several BFTAs have agreed between both developed and developing countries. In addition, BFTA between Indonesia and its country trading partner will also be analysed, especially Indonesia-Japan Economic Partnership Agreement (IJEPA).

This research uses primary and secondary legal sources. The primary sources constitutes authorative sources in nature in the meaning that this source is 
made by legal authority bodies officially. It consists of legislations, regulations, official records, and treatise in legislations. While secondary legal materials constitutes all forms of publication which is not an official document, which consists of: textbooks, law dictionaries, legal journals, and comments on court decision.

\section{Discussion and Result}

\section{TRIPs-Plus Provisions on Patent in the BFTAs between both Developed and Developing Countries in General}

Patent protection is unquestionably important. What is cause for concern, however, is the excessive exclusivity and over protection promoted by BFTAs. This because BFTAs are powerful legal instruments that can impose excessive exclusivity on IP standards, such as: (1) the elimination of several options and flexibilities provided by TRIPs ${ }^{20}$; (2) the extension of the scope of protection; (3) the simplification of the requirements for granting IPR; and (4) the strengthening IPR enforcement through a well-developed monitoring system. ${ }^{21}$

Research of various BFTAs that exist between the US and its trade partners have concluded that certain common aspects go beyond the TRIPs Standart on Patent, although detail provisions differ from agreement to agreement. ${ }^{22}$ These common aspects include: (1) the extension of patent terms for delay due to regulatory approval processes and delays in issuing patents; ${ }^{23}$ the requirement to provide patents for new methods of producing known products; 24 (3) the patentability of life forms by elimination of Article 27 (3) (b) of the TRIPs

${ }^{20}$ Henning Grosse Ruse-Khan, Op.Cit., p.1.

${ }^{21}$ See in general, Carlos M. Correa, "Implication of Bilateral Free Trade Agreement on Access to Medicines", Bulletin of the World Health Organization, Vol. 84, No. 5, 2006, and Peter Drahos, "BITs and BIPs; Bilateralism in Intellectual Property", Journal of World Intellectual Property, Vol 4, 2001, pp.791-808.

${ }^{22}$ Fink and Patrick, "Tightening TRIPs; The Intellectual Property Provisions of Recent US Free Trade Agreement," Trade Note 20, The Word Bank Group, 2005, p. 2.

${ }^{23}$ The extension of patent term due to "regulatory approval process" can be found in the BFTAs between the United States and several countries such as, Vietnam, Jordan, Singapore, Chili, Morocco, Australia, CAFTRA and Bahrain. Bahrain.

${ }^{24}$ See for examples, BFTAs between the United States and several countries like Australia, Marocco, and 
Agreement; ${ }^{25}$ (4) the limitation of Compulsary License; ${ }^{26}$ (5) the prohibition of marketing approval for a generic drug during the patent term without authorisation from the patent owner; ${ }^{27}$ (6) the protection of test data for pharmaceutical products;28 and (7) the limitation of parallel imports through licence contracts. ${ }^{29}$ Analysis of these aspects is outlined as follows:

Firstly, the extension of patent terms. Prior to market entry, pharmaceutical and agrochemical companies are required to obtain official approval from a national health agency. This is normally a lengthy process that can take up to several years. For the purpose of protecting the inventions' exclusive rights, BFTAs are created to link directly with the patent system and the drug administration process to extend the patent term as a compensation for the loss of those rights. Such provisions have been implemented in the US and other developed countries under the "Hatch-Waxman Act." 30

This extension is to allow the patent holder to enjoy the economic benefits that could not be obtained during the approval process. The US-Singapore FTA demands such an extension of patent because of unreasonable delays in the granting of patents. ${ }^{31}$ Consequently, the extension of patent terms also delays the introduction of affordable generic drugs, depriving consumers of the benefits of generic competition. This introduces even greater risks to the public health of developing countries, which are already at a disadvantage due to pharmaceutical patents. This extension will also mean that patent-holder will continue to have a monopoly even after the expiration of patent term. ${ }^{32}$

${ }^{25}$ Although detailed provision is different, see for examples, BFTAs between the US and several countries like, seperti Vietnam, Jordan, Singapura, Chili, Morocco, Australia dan Bahrain.

${ }^{26}$ Ibid., only BFTAs between the US and Chili, Morocco and Bahrain which implement TRIPs Standard, the rest go beyond TRIPs.

${ }^{27}$ Only BFTA between the US and Vietnam which does not apply this requirement.

${ }^{28}$ This protection is 5 years from the date of marketing approval for new pharmaceutical products and 10 years for new agrochemical products.

${ }^{29}$ See BFTAs between the US and several countries like Australia, Singapura, Morocco. Although other BFTAs still implements TRIPs standard.

${ }^{30}$ See the Drug Price Competition and Patent Term Restoration Act of 1984, known the Hatch-Waxman Act. Pub. L. No. 98-417, 98 Stat. 1585 (codified at 21 U.S.C. 355(b), (j), (1); 35 U.S.C. 156, 271, 282).

${ }^{31}$ See BFTAs between the US and Singapore, Article 16.7.7, 16.7.8 and 16.8.4.

${ }^{32}$ Kuanpoth, "Current Development and Trends in the Field of Intellectual Property Rights; Harmonisation through Free Trade Agreement, a Paper presented at the UNCTAD/ICTSD/HKU/IDCR Regional Dialouge Intelelctual Property Rights (IPRs), Innovation and Sustainable Development, Hong Kong, SAR, 8-10 November, p. 14. 
Secondly, the limitation of compulsory license. This license provides an important safe guard for public health and now can be found in all IP system. ${ }^{33}$ Such licenses are used to balance the rights of patent holders on one hand, and the broader public interest on the other. ${ }^{34}$ These non-voluntary licenses are issued by a state, and authorise a third party to produce a cheap generic versions of patented products, with condition that the licensee pays reasonable compensation to the patent holder. The World Health Organization (WHO) has suggested such licenses can be used to ensure that the price of drugs is in harmony with local purchasing power and to 'avoid abuse of patent rights and a national emergency'. ${ }^{35}$

Compusory License in countries such as US, Canada, and Brazil have helped to reduce the price of medicines and can be an effective way to restrict the abusive practices of patent holders. ${ }^{36}$ On the other hand, from the perspective of researchbased pharmaceutical industries, this licence is a trade distortion because it uses the patents against the will of the patent holders. Accordingly, pharmaceutical companies oppose this approach ${ }^{37}$ as it discourage investment, research, and development. ${ }^{38}$ It is interesting to note that countries that use compulsory licenses are often subject to economic coersion, although the TRIPs Agreement provides this flexibility. As a result, Doha Declaration on the TRIPs Agreement and Public Health reminded WTO Members to use this legal measure legitimately as a way to improve access to affordable medicines.

Article 31 of the TRIPs Agreement allows member countries to grant compulsory licenses on the basis that they are determinated by each member. It also specifies some reasons why member countries might choose to grant compulsory licenses, whilst recognising that other reasons may exist. However,

\footnotetext{
${ }^{33}$ Majority of Patent Act in developed countries also regulates the use of compulsory license.

34"Undermining Access to Medicines; Comparison of Five US FTA's; A Technical Note", Oxfam International Briefing Note, Oxfam 2004, p. 9.

${ }^{35}$ See in general, Carlos M Correa, Integrating Public Health Concern into Patent Legislation in Developing Countries, South Centre, Geneva, 2000, p. 94.

${ }^{36}$ Kuanpoth, Op. Cit, p. 9.

${ }^{37}$ Gibson, Christopher, "Look at the Compulsory License in Investment Arbitration: The Case of Indirect Expropriation, American University International Law Review, Vol. 25, 2010, p. 357; See also Subhasis Saha, "Patent Law and TRIPS: Compulsory Licensing of Patents and Pharmaceuticals", Journal of Patenter Trademark Office Society, Vol. 91, 2009, p. 364.

${ }^{38}$ Carlos M Correa, Integrating Public Health,... Op. Cit.
} 
bilateral mechanisms tend to limits the right of countries to use this approach. The US-Singapore BFTA for example set forth a parameter for using compulsory licenses, limiting their use to the remedy of anti-competitive behaviour, ${ }^{39}$ public non-commercial use, ${ }^{40}$ and national emergencies. ${ }^{41}$ This provision prevents the countries involved from issuing compulsory licenses in circumstances outside those three conditions.

Furthermore, the US-Singapore BFTA also sets a higher standard of compensation for the use of such licenses. ${ }^{42}$ Parties can not require the transfer of test data or know-how in relation to production under compulsory licenses. This limits access to medicines in some countries. According to Kuanpoth, BFTA between Thailand and the US would limit access to medicines for not only Thai people, Vietnam, Myanmar and Cambodia. ${ }^{43}$

Thirdly, the limitation of parallel importation. Similar to compulsory licenses, parallel importation is an instrument used by developing countries to access affordable medicines through importing patented drugs from other countries which are approved for domestic sale at a lower price. This mechanism is allowed under the TRIPs Agreement and a country has the right to determine its own rules on parallel importation. However, BFTAs between the US and other countries usually impose limits on the use of parallel importation. ${ }^{44}$

It is also important to note that the Indonesian Patent Act makes an exception from criminal liability for parallel importation of pharmaceutical protected under the law, particularly if the products have been marketed abroad by the patent holder and imported into Indonesia in accordance with relevant regulation. ${ }^{45}$ Furthermore, bolar exception ${ }^{46}$ is allowed and exempted from criminal liability (Article $135 \mathrm{~b}$ ).

\footnotetext{
${ }^{39}$ Anti competitive practice includes excessive price correction and other misuse uses.

${ }^{40} \mathrm{The}$ non commercial use by public means the use for public interest, and not for commercial interest.

${ }^{41}$ Like when there is an urgent interest for public health as result of natural disaster, war or epidemic like $\mathrm{HIV} / \mathrm{AIDS}$ in several African nations, or health emergency condition.

${ }^{42}$ See section 6 (b) (ii) US-Singapore BFTA.

${ }^{43}$ Thailand will unable to issue the use of license for compulsory license or experting drugs under compulsory license to neighbour countries, Kuanpoth, Op. Cit.See also Kristina M. Lybecker and Elisabeth Fowler, "Compulsory Licensing in Canada and Thailand: Comparing Regimes to Ensure Legitimate Use of the WTO Rules", The Journal of Law, Medicine \& Ethics, Vol. 37, Issue 2, 2009, pp. 222-239.

${ }^{44}$ Ibid.

${ }^{45}$ See Article135 (a) of the Patent Act

${ }^{46}$ Bolar Exception knows also as Early working exception.
} 
Fourthly, prohibition of patent revocation. TRIPs also allows patent revocation, although the agreement does not set out any conditions for such revocation. However, BFTAs between the US and its trading partners prohibit patent revocation because it undermines patentability, and can lead to nondisclosure, insufficiency of or unauthorised amendments to the patent specification, fraud, or misrepresentation. ${ }^{47}$

Interestingly, Palombi argues that the actual meaning of the word "invention" under the Article 27.1 of the TRIPs does not include natural products, natural phenomena and their artificial derivatives. This meaning is consistent with the fundamental principle of patent law: that a patent can only be applied to an "invention" that is "novel", "involve an inventive step" and is "industrially applicable". However, Palombi has confirmed that most biotechnology patents granted in developed countries that "are identical, or materially identical to natural phenomena, that are contrary to and violation of TRIPs". ${ }^{48}$ Because of such violations that patents are deemed "void" and are revoked. Accordingly, any provision which prohibit the revocation of "bad patents" contravene prininciple to freely access natural products.

Furthermore, protection of data exclusivity. In most jurisdictions, pharmaceutical and agrochemical products must be registered before entering into market. For the purpose of registration, the companies involved are required to complete a data test regarding the quality, safety and efficacy of the products (known as the test data). Considerable effort goes into compiling such data, which thus needs protection. Under the TRIPs Agreement, all member countries must submit undisclosed data for marketing approval, and to avoid "unfair commercial use" or "disclosure" of such data. ${ }^{49}$ The TRIPs does not protect the data exclusivity of the first person who submits marketing approval data to the national drug regulatory authority.50It provides an opportunity for member countries to determine the rules for the protection of undisclosed test data. In

${ }^{47}$ See US-Singapura BFTA, Article 16.7.4.

${ }^{48}$ Ibid., p. 222

${ }^{49}$ Article 39.3 of TRIPs Agreement.

${ }^{50}$ Carlos M. Correa, Integrating Public Health, Op. Cit. 
practice, the general drugs manufacturer can rely on the date submitted by the original company to get the marketing approval on similar products.

However, US BFTAs generally enforces data exclusivity for at least five years on pharmaceutical and ten years on agricultural chemicals. It also prohibits generic manufacturers from relying on the test data submitted by the original company. US BFTAs also require that protection must be exclusively provided for all kind of data submitted for marketing approval, not only new chemical entities, but also compositions, dosage forms, and the new use of an already known drug. This provision generally restricts a country's ability to implement Article 39.3 of TRIPs. Apart from that, it also inhibit generic drugs from entering the market because testing and registration process is expensive and time-comsuming. Furthermore, it diminishes the possibility of compulsory licences since the relevant and essential data are not available due to exclusive protection. It means that data exclusivity extends the monopoly of patent holders. It also enforces hard penalties, including criminal sentences for violation and infringement of IPR, as well as impeding the use of compulsory licences and other mechanisms to protect public health in developing countries trading with the US.

Moreover, patenting life forms. A generally accepted principle of patent law is that life forms can not patentability. This principle, however, does not extend to practice. The scope of patents has been extended to include life forms and living organism such as micro-organisms. Advances in biotechnological invention, innovation, and its applications have challenged patent theory, raising questions on how such technologies fit into the notion of patent law in general, and how to satisfy collective patentability thresholds in particular. Thus, the fundamental question around this issue concerns the legal validity and morality of such patent, particularly when it involves human body parts, like human DNA and genes. ${ }^{51}$

TRIPs lays the foundation for the protection of life forms, although on a theoretical basis, it could be criticised because life forms do not fall within the category of "invention" by virtue of Article 27.1. But Calvalho argues that patent 
is technologically neutral, ${ }^{52}$ and should thus be given to all types of technology without discrimination. ${ }^{53}$ Under US-BFTAs, the US tends to emphasise thes principle. For example, the US-Singapore BFTA states that "each party may exclude inventions from patentability only as defined in Article 27.2 and 27.3 (a) of the TRIPs Agreement". ${ }^{54}$ It means that all categories of life-form is patentable, including genes and genes sequences.

TRIPs-Plus Provisions on Patent in the BFTA between Indonesia and Its Trading Partner

Indonesia has already signed an BFTA with Japan in the frame of "IndonesiaJapan Economic Partnership Agreement (IJEPA)" in 2007. Related to the protection of IPR, IJEPA regulates it in Chapter 9, from Articles 106 to 123 (consists of 17 Articles). ${ }^{55}$ Under that Chapter, there are some TRIPs-Plus provisions, whether in the field of copyrights, trademark, patent, protection of plant varieties and other field of IPRs. Based on general provision stipulated under Article 106 (1) it states that:

The Parties, aiming at further promoting trade and investment, shall grant and ensure adequate, effective and non-discriminatory protection of intellectual property, promote efficiency and transparency in the administration of intellectual property protection system, and provide for measures for the enforcement of intellectual property rights against infringement, counterfeiting and piracy, in accordance with the provisions of this Chapter and the international agreements to which both Parties are parties.

Based on the above provision, it can be interpreted that after Indonesia signing this Agreement, Indonesia is not only bound TRIPs Agreement, but also other international law in which both countries become party to those Agreements, including this IJEPA. Article 106 (2) then stipulates that:"The Parties reaffirm their commitment to comply with the obligations set out in the international agreements relating to intellectual property to which both Parties are parties."

\footnotetext{
${ }^{52}$ Carvalho, Nuno Pires de, The TRIPs Regime of Patent Right, 2nd Edition, The Netherlands, Kluwer Law International, 2005, p. 9.

${ }^{53}$ Article 27 of the TRIPs Agreement

${ }^{54}$ US-Singapore BFTA, Article 16.7.1.

${ }^{55}$ See also in Nurul Barizah ,TRIPs-Plus..., Op.Cit., p. 13
} 
In the context of patent procedure, Article 109 regulates that each party shall have an endeavour to increase the number of "patent attorney" or registered IPR Consultant in the light of facilitating the grant and the use of industrial property. ${ }^{56}$ The Article also states that registration for and the grant of patent and its publication shall clasified based on international patent classification system which have been establised under "Strasbourg Agreement concerning the International Patent Classification of March 24, 1971", as ammended. ${ }^{57}$

Furthermore, IJEPA recognises the important of transparency in the protection of IPR, including administration process as enshrined in the Article 110 which requires each party to take appropriate measure to publish information for promoting transparency in the administration sistem of IPR protection in accordance with its the law and regulations, covering utility model registration and the archives derived from it. ${ }^{58}$ This public information shall also includes statistic infomation in its effort to provides an effective enforcement of IPR protection and other information relevant to the IPR system, including guideline standard on examination of patent application. ${ }^{59}$

Article 122 IJEPA then regulates on patent specifically, and states that:"Each Party shall ensure that any patent application is not rejected solely on the ground that the subject matter claimed in the application is related to a computer program". ${ }^{60}$ This means that computer program also can be patented based on IJEPA's Article 122 above. While, under Indonesia national law on IPR, computer program is protected by Copyright Act. It means that IJEPA establishes a higher standart of protection on computer program compared to the TRIPs Agreement.

Still in the context of patent application procedure, Article 112 (2) IJEPA states that:

Each Party shall ensure that an applicant may, on its own initiative, divide a patent application containing more than one invention into a certain number of divisional patent applications within the time limit provided for in the laws and regulations of the Party.

\footnotetext{
${ }^{56}$ Article 109 (7) IJEPA.

${ }^{57}$ Article 109 (8) IJEPA

${ }^{58}$ Article 110 (a) IJEPA

${ }^{59}$ Article 110 (c) IJEPA

${ }^{60}$ Article 112 (a) IJEPA
} 
This Article emphases that if an patent application consist of more than one invention, it can be applied for more than one patent, in the meaning that such patent application can be devided into several inventions and each invention can be patented separately. The provision to provides a lower standard of patentability of the invention like in the above Article is very important for developed country like Japan, which have a big number of national patent application. But it does not advantage Indonesia because this country does not have national patent application as many as Japan. By dividing one patent application into several inventions which can be protected separately, it can contribute to the lack of quality and integrity of patent protection as an exclusive right. It also provides an opportunity to patent inventions in which in principles can not meet the criterias of patentabilities, like inventions which are lack of novelty, and do not constitute an inventive step.

Furthermore, in relation to the substantial examination process of patent application, IJEPA stipulates that:

Each Party shall ensure that an application for a patent is examined upon the request of the applicant, where appropriate, in preference to other applications, if the applicant has filed an application for a patent of the same or substantially the same invention in the other Party or in any non-Party. Each Party may require the applicant to furnish, together with the request, a result of relevant prior art search, or a copy of the final decision by the administrative authority for patents of the other Party or of a non-Party (hereinafter referred to in this Article as "the final decision") on the application filed in the other Party or in the non-Party. ${ }^{61}$

This Article reaffirms the important of recognition of prior art result which have been searched by patent offices of both Party or non Party of this IJEPA. This is in line with spirit of patent application through Patent Cooperation Treaty (PCT) ${ }^{62}$ which has the main function to foster the patent application process worldwide. Still in similar context, Article 112 (4) also states that:

Notwithstanding paragraph 3, a Party which requires, pursuant to relevant provisions of its laws and regulations, the applicant who filed an application for a patent in that Party to furnish a copy of the final decision on an application for a patent of the same or substantially the same invention which the applicant filed in the other Party or in any non-Party, shall examine the

${ }^{61}$ Article 112 (3) IJEPA.

${ }^{62}$ Patent Cooperation Treaty, Done at Washington on June 19, 1970, amended on September 28, 1979, modified on February 3, 1984, and on October 3, 2001 (as in force from April 1, 2002) 
application in preference to other applications, if the applicant furnishes the aforementioned copy.

This Article confirms and agrees that patent application filled in a state Party to this agreement must be prioritised if the patent has been registered either in the state or non-state Party, if the application completes the final decision of patent application on the same invention or substantially the same in both Party or non Party. This provision also contains the same spirit with patent protection through PCT.

Interestingly, this IJEPA does not recognise unwritten "prior art". While in traditional culture like Indonesia, many traditional knowledge that has been developed in the society from generation to generation, particularly for traditional medicinal knowledge. This unwritten "prior art" can be used to reject the novelty of an invention derived from traditional knowledge derived from "missappropriation" or "misuse use of such knowledge. If the cancellation of the novelty of invention is only determined by written "prior art", it is very difficult to prevent misappropriation of traditional knowledge. TRIPs Agreement does not require "prior art" in writing. This means that the TRIPs provides flexibility to the national patent laws to acknowledge the existance of unwritten or spoken language or oral "prior art". However, IJEPA only requires in writing as stipulated as follows:

Each Party shall ensure that any person may provide the administrative authority for patents with information in writing that could deny novelty or inventive step of inventions claimed in patent applications during the pendency of those applications. Each Party shall take the information, as appropriate, into consideration for examining those applications. ${ }^{63}$

Furthermore, still in the context of administrative procedure, if patent application is rejected, then after the petition of appeal, the applicant is given the possibility to change the patent application within a specific period of time based on Article 112, as follows:

Each Party shall ensure that an applicant may make amendments to its patent application within a certain period, in accordance with the laws and regulations of the Party, after the filing of its appeal petition with respect to the refusal of such application by the administrative authority for patents. ${ }^{64}$ 
The Article above gives a wider possibility for an invention to be patented and not rejected by the Patent Office of Party to IJEPA. This lead to the emergence of unqualified patents due to lack of novelty and inventive step. Such provision also provide an opportunity for Party, advanced in technology, like Japan for patenting as many inventions invented by citizens in other Party, lack of technological invention.

Moreover, IJEPA sets more stringent regulation related to patent infringement whether for product and process patents as Article 112 (7) stipulates that:

Each Party shall provide that at least the following acts shall be deemed as an infringement of a patent right if performed without the consent of the patent owner:

(a) in the case of a patent for an invention of product, acts of manufacturing, assigning, leasing, importing, or offering for assignment or lease, for commercial purposes, things to be used exclusively for the manufacture of the product; and

(b) in the case of a patent for an invention of process, acts of manufacturing, assigning, leasing, importing, or offering for assignment or lease, for commercial purposes, things to be used exclusively for the working of such invention.

In addition, IJEPA uses instrument of criminal law, imprisonment and fines for the infringement of all areas of IPR, including patent, as stipulated under Article 121, which states that:

Each Party shall provide for criminal procedures and penalties to be applied in cases of the infringement of patent rights, rights relating to utility models, industrial designs, trademarks or layout-designs of integrated circuits, copyrights or related rights, or plant breeder's rights, committed willfully and on a commercial scale. Remedies available shall include imprisonment and/or monetary fines sufficient to provide a deterrent, consistently with the level of penalties applied for crimes of a corresponding gravity.

The last Article in IJEPA on IPR requires the establishment of the subcommission on IPR with the objectives to support the operational application and effective implementation of this IJEPA. The function of this sub-commission are as follows: (1) reviewing and monitoring the implementation and operation of IPR; (2) discussing any issues related to IPR with a view to enhancing IPR protection, enforcement, and to promoting efficient and transparent administration; (3) exchanging views on the issues of protection of genetic resources, traditional knowledge and folklore; and liability of internet service providers; (4) reporting the findings of the Sub-Committee to the Joint Committee; and (5) carrying out 
other functions as may be delegated by the Joint Committee in accordance with Article $14 .{ }^{65}$

All above Articles on enforcement has shown that enforcement of patent rights under IJEPA is more stricten than provided by TRIPs Agreement and IJEPA consists a number of TRIPs-Pus provisions, as contained in other BFTAs.

\section{Amendment of Indonesian Patent Act; Is it Necessary to Comply with Bilateral Commitment?}

After signing the Agreement, usually it is unvitable that national legislation should be amended to comply with this bilateral commitment. The following examines certain Articles in the Indonesia Patent Act ${ }^{66}$ that may required to be amended, and whether Indonesia should amend it to the best interest of Indonesia.

Firstly, the provision of Article 3 which stipulated that: (1) an invention shall be considered novel, if at the date of filing of the application said invention is not the same with any previously technological disclusure. (2) a technological disclosure as reffered to in paragraph (1) is one which has been announced in Indonesia or outside Indonesia in writing, by a verbal description or by a demonstration, or in other ways, which enable a skilled person to implement the invention before; a. Filing date, or b. Priority date.

The above Article recognises "prior art" in the form of writing, verbal description (oral) or by demonstration provided that a skilled person able to implement the invention. While under the IJEPA, as mentioned earlier, only recognises "prior art" in the form of writing. Athough like that, it would be better for Indonesia to leave this Article 3 unchanged to protect Indonesian traditional knowledge.

Secondly, Indonesian Patent Act regulates unpatentable inventions, as follows: a patent shall not be granted to an invention regarding: a. any process or product of which the announcement and use or its implementation contravenes the prevailing rules and regulations, religious morality, public order or ethics; $b$. any method of examination, treatment, medication, and/or surgery applied to

${ }^{65}$ Ibid.

${ }^{66}$ The Act of Republic of Indonesia No 14 of 2001 on Patent, State Gazette 2001 No 109, Supplemetary State Gazette No 4130, enacted on August1, 2001, entered into force, August 1, 2001. 
humans and /animals; c. any theory and method in the field of science and mathematics; d. i. All living creatures, except micro-organism; ii. Any essential biological process for producing plant or animal, except non biological process or microbiological process. ${ }^{67}$

It would also be better if this Article also remain unchanged although IJEPA implisitly insists computer program should be protected under Patent Act.

Thirdly, Article 21 of Indonesian Patent Act provides that "Each application can only be filed for one invention, or several inventions that constitute a unity of invention" should also be remain unchanged to avoid and prevent bad patent (lack of quality).

Forthly, in the context of rights and obligations of patent holder, Article 16 (1) of the Indonesia Patent Act states that " a patent holder shall have the exclusive right to exploit his Patent and prohibit any other party who without his consent" for product-patent to "makes, makes, uses, sells, imports, rents out, delivers, or makes available for sale or rental or delivery of the patented product".

The above Article shows that Indonesia prohibit paralel importation. Then Article 130 recognised that paralel importatation is criminal offence as it states that:

Any person who deliberately and without rights infringes the rights of a patent holder by committing one of the acts as referred to in Article 16 shall be sentenced to imprisonment of at most 4 (four) years and/or a fine of at most Rp. 500.000.000,00 (five hundred million rupiahs)

However, Article 135 (a) excludes from criminal sanction paralel importation for pharmaceutical products after the patent holder put the products into market. Article 135 (a) stipulates that excepted from criminal provision is "Importation of a pharmaceutical product protected by a patent in Indonesia and that the product has been marketed in a country by the right Patent Holder provided that the product is imported in accordance with the prevailing rules and regulations."

The existance of the above Articles in the context of paralel importation remains unclear, whether Indonesia prohibit paralel importation or not. Furthermore, Article 118 (1) stipulates that: "A patent holder or a licensee shall be entitled to bring a lawsuit for damages through the Commercial Court against any person who deliberately and without rights performs any acts as referred to in Article 16". 
This Article shows that patent holder still have a right to claim damage resulted from paralel importation activity. This shows two things: Firstly, it is unclear on what basis the patent owner can claim damages against the parallel importer. Secondly, it is also unclear whether the first sale by a licensee or assignee exempts the parallel importer from penal sanction.

This means that the provisions of the Patent Act exceed the provision stipulated in the TRIPs Agreement. Indonesia also does not use any flexibility set out in the Article 28 (1) TRIPs. Whereas Article 28 (1) applies Article 6 which gives leeway to Member states on the principle of exhaustion, and it should be used as well as possible by Indonesia. Indonesia could subject to exclusive right to prohibit an authorised importation to the exhaustion principle.

It is important to note that in the process of amendment, to take into consideration national interest, and not merely to serve bilateral commitment. It means that both national interest and bilateral commitment should be taken into account in the amendment of Patent Act.

\section{Conclusion}

The provisions of BFTAs in the field of IPR agreed by both developed and developing countries generally contains TRIPs-Plus Standard for all areas of IPR, including Patent. TRIPs-Plus standard imposed in the BFTAs for developing countries trading partner by developed countries because they demand a higher standart of IPR protection than standards provided in the multilateral agreement.

IJEPA also contain TRIPs-Plus provisions on patent, not only in the substance of protection and administrative procedures, but also stricten its enforcement. IJEPA mandates the establishment of sub-commissons on IPR for operational framework and implementation of the Agreement in order to be adhered by the Parties. The provisions of TRIPs-Plus is very unfavorable for Indonesia as Party that does not produce a lot of inventions in the field of technology and application of patent by national is still very low compared to its trading partner. 
As consequence, there are a number of provisions in the field of patent that may require to be adjusted in line with IJEPA, such as the provision on "prior $\operatorname{art}^{\prime \prime}$, the provision on patentable and unpatentable inventions, the provisons on sentencing, the provision on parallel imports, the provisions on exhaustion principle, and others. Accordingly, it is important for Indonesia to consider national interest in the revision of Patent Act and not merely for adherance to bilateral commitment.

\section{Literatures}

"Undermining Access to Medicines; Comparison of Five US FTA's; A Technical Note", Oxfam International Briefing Note, Oxfam 2004.

Abbott, F. M., "Intellectual Property Provisions of Bilateral and Regional Trade Agreement in the Light of US Federal Law", International Centre for Trade and Sustainable Development, Issue Paper No 12, http://www.ipronline.org/unctadictsd/description.htm, accessed on 2 June 2014.

Agreement between Japan and the Republic of Indonesia for an Economic Partnership, signed in Jakarta, 21 August, 2007.

Agreement on Trade Related Aspects of Intellectual Property Rights (TRIPs) of 1994. (Marrakesh Agreement Establishing the World Trade Organization, Annex 1C, 15 April 1994, 33 I.L.M. 1197, 1201 (entered into force on 1' January 1995).

Barizah, Nurul, "TRIPs Plus on Plant Varieties Protection under Indonesia-Japan Economic Partnership Agreement (IJEPA)", Yuridika, Vol. 24, No 1, 2009.

Candra, Alexander C. (ed.), Checkmate! The US- Indonesia Bilateral Free Trade Agreement, Institute for Global Justice, Jakarta, 2007.

Carroll, Micheal W., "One Size Does Not Fit All: A Framework for Tailoring Intellectual Property Rights", Ohio State Law Journal, Vol 70:6, 2009.

Carvalho, Nuno Pires de, The TRIPs Regime of Patent Right, 2nd Edition, The Netherlands, Kluwer Law International, 2005.

Correa, Carlos M, Integrating Public Health Concern into Patent Legislation in Developing Countries, South Centre, Geneva, 2000.

, "Implication of Bilateral Free Trade Agreement on Access to Medicines", Bulletin of the World Health Organization, Vol. 84, No. 5, 2006.

Deere, Carolyn, The Implementation Game; The TRIPs Agreement and the Global Politics of Intellectual Property Reform in Developing Countries, Oxford University Press, 2009. 
Drahos, Peter, "BITs and BIPs; Bilateralism in Intellectual Property", Journal of World Intellectual Property, Vol 4, 2001.

Drahos, Peter, "Expanding Intellectual Property's Empire; The Role of FTA's, at $<$ http://bilateral.org/IMG/doc/Expanding_IP_Empire_Role_of_FTAs.doc $>$ accessed on 2 June 2014.

Framework on Comprehensive Economic Co-Operation between ASEAN and the People's Republic of China, Phnom Penh, 5 November 2002.

Gervais, Daniel (ed.), Intellectual Property, Trade and Development; Strategies to Optimize Economic Development in a TRIPs-Plus Era, Oxford University Press, 2007.

Gibson, Christopher, "Look at the Compulsory License in Investment Arbitration: The Case of Indirect Expropriation, American University International Law Review, Vol. 25, 2010.

Grosse Ruse-Khan, Henning, “The International Law Relation between TRIPS and Subsequent TRIPS-Plus Free Trade Agreements: Towards Safeguarding TRIPS Flexibilities?", Journal of Intellectual Property Law, Vol. 18, No. 2, 2011.

Heydon, Kenneth and Woolcock, Stephen, The Rise of Bilateralism; Comparing American, European and Asian Approaches to Preferential Trade Agreements, United Nations University, 2009.

Khor, Martin, Bilateral and Regional Free Trade Agreement; Some Critical Elements and Development Implications, TWN Third World Network, Malaysia, 2008.

Kuanpoth, "Current Development and Trends in the Field of Intellectual Property Rights; Harmonisation through Free Trade Agreement, a Paper presented at the UNCTAD/ICTSD/HKU/IDCR Regional Dialouge Intelelctual Property Rights (IPRs), Innovation and Sustainable Development, Hong Kong, SAR, 8-10 November.

Lybecker, Kristina M. and Fowler, Elisabeth, "Compulsory Licensing in Canada and Thailand: Comparing Regimes to Ensure Legitimate Use of the WTO Rules", The Journal of Law, Medicine E Ethics, Vol. 37, Issue 2, 2009.

Moore, Mike, A World Without Walls; Freedom, Development, Free Trade and Global Governance, Cambridge University Press,Cambridge, United Kingdom, 2003.

Morin, Jean-Frédéric, "Multilateralizing TRIPs-Plus Agreements: Is the US Strategy a Failure?"The Journal of World Intellectual Property, Vol. 2, Issue 3, 2009.

Patent Cooperation Treaty, Done at Washington on June 19, 1970,amended on September 28, 1979,modified on February 3, 1984, and on October 3, 2001(as in force from April 1, 2002).

Patrick and Fink, "Tightening TRIPs; The Intellectual Property Provisions of Recent US Free Trade Agreement," Trade Note 20, The Word Bank Group, 2005. 
Patry, William, How to Fix Copyright, Oxford University Press, USA, 2012.

Reichman, J., "Charting the Collape of the Patent-Copyright Dichotomy: Premises for a Restructured International Intellectual Property System", Cardozo Art and Entertainment Law Journal, Vol 13, 1994.

Saha, Subhasis "Patent Law and TRIPS: Compulsory Licensing of Patents and Pharmaceuticals", 91 Journal of PatentE Trademark Office Society, Vol. 91, 2009.

Sanders, Anselm Kamperman, "Intellectual Property Treaties and Development", in Daniel Gervais (ed.), Intellectual Property, Trade and Development; Strategies to Optimize Economic Development in a TRIPs-Plus Era, Oxford University Press, 2007.

Sell, Susan K., “TRIPs Was Never Enough: Vertical Forum Shiftings, FTAs, ACTA, and TPP", J. Intellectual Property Law, Vol. 18, 2010-2011.

The Act of Republic of Indonesia No 14 of 2001 on Patent, State Gazette 2001 No 109, Supplemetary State Gazette No 4130, enacted on August1, 2001, entered into force, August 1, 2001. 